\title{
40. CAUSES OF THE OXYGEN ISOTOPIC DEPLETION OF INTERSTITIAL WATERS FROM SITES 798 AND 799, JAPAN SEA, LEG $128^{1}$
}

\author{
Ryo Matsumoto ${ }^{2}$
}

\begin{abstract}
Oxygen isotope compositions of the interstitial waters have been measured for 21 samples taken from the depth intervals of 1.5 to $398.9 \mathrm{mbsf}$ at Site 798 (Oki Ridge) and 16.5 to $435.6 \mathrm{mbsf}$ at Site 799 (Kita-Yamato Trough) in Japan Sea. The $\delta^{18} \mathrm{O}$ values decrease with depth from -0.49 to $-3.38 \%$ (SMOW) at Site 798 and from -0.71 to $-4.36 \%$ (SMOW) at Site 799 corresponding to an average depletion gradient of $-0.8 \%$ oper $100 \mathrm{~m}$. Material balance calculations reveal that the $\delta^{18} \mathrm{O}$-variations at Sites 798 and 799 were principally controlled by low-temperature alteration of basement basalt and andesite, resulting in negative shifts in pore water $\delta^{18} \mathrm{O}$ values, and by the polymorphic transformations of biogenic opal-A to opal-CT and opal-CT to microquartz, which tend to increase $\delta^{18} \mathrm{O}$ of interstitial waters. Carbonate diagenesis and ash alteration also caused weakly negative shifts in pore water $\delta^{18} \mathrm{O}$ values.
\end{abstract}

\section{INTRODUCTION}

Isotopic studies of interstitial waters recovered from sediments at hundreds of DSDP/ODP sites in the world ocean demonstrate that, in most cases, the $\delta^{18} \mathrm{O}$ values are depleted relative to seawater (e.g., Lawrence, 1973; Lawrence et al., 1975; Matsuhisa and Matsumoto, 1985; Vrolijk et al., 1990; Boulegue and Bariac, 1990). The mechanisms ascribed to these variations include: (1) secular variation of seawater $\delta^{18} \mathrm{O}$ (Bath and Shackleton, 1984), (2) migration and mixing of isotopically light oxygen waters (Vrolijk et al., 1990; Boulegue and Bariac, 1990), (3) diagenetic reactions within sediments during burial (Lawrence, 1973; Matsuhisa and Matsumoto, 1985), (4) alteration of basement rocks (Lawrence el al., 1975; Stern et al., 1976; Vrolijk et al., 1990), (5) hyperfiltration and osmotic effects (Matsuhisa and Matsumoto, 1985; Boulegue and Bariac, 1990), and (6) decomposition of gas hydrates (Hesse and Harrison, 1981; Jenden and Gieskes, 1983; Matsumoto, 1989). The present study reveals that $\delta^{18} \mathrm{O}$ values of interstitial waters extracted from Neogene sediments at two Japan Sea sites decrease with depth with an average gradient of $-0.80 \%$ oo per $100 \mathrm{~m}$. The purpose of this report is to evaluate the relative contribution of sediment diagenetic reactions and basalt alteration in controlling observed $\delta^{18} \mathrm{O}$-variations of interstitial waters at ODP Sites 798 and 799 in the Japan Sea.

\section{SITE DESCRIPTIONS AND SEDIMENT LITHOLOGY}

\section{Site 798}

Site 798 is located in a small basin atop Oki Ridge, under $903 \mathrm{~m}$ of water (Fig. 1). The seismic records show that total sediment thickness at Site 798 is approximately $710 \mathrm{~m}$ (Shipboard Scientific Party, 1990a-g). A 519.7-m-thick, upper lower Pliocene through Holocene sedimentary section is divided into three lithologic units.

Unit I (0-220 mbsf; latest Pliocene to latest Quaternary) is composed of clay, diatomaceous clay, and diatomaceous ooze. This unit is characterized by decimeter- to meter-thick rhythmic interbeds of dark-colored, thinly laminated sediments and light-colored, bioturbated intervals. Biogenic carbonate content ranges up to $40 \%$ but averages around $15 \%$. A hard dolomitic layer $33 \mathrm{~cm}$ thick occurs at 143 mbsf. Unit II (220-455 mbsf; late Pliocene) consists of moderately indurated, bioturbated diatomaceous clay interbedded with dia-

\footnotetext{
${ }^{1}$ Pisciotto, K. A., Ingle, J. C., Jr., von Breymann, M. T., Barron, J., et al., 1992. Proc. ODP, Sci. Results, 127/128, Pt. 1: College Station, TX (Ocean Drilling Program).

${ }^{2}$ Geological Institute, University of Tokyo, Hongo, Tokyo, Japan.
}

tom ooze and silty clay. Biogenic carbonate content is less than in Unit I, mostly less than 4\%. Fragments of dolomite concretions, $1-3 \mathrm{~cm}$ in diameter, were found at 334.0 mbsf and 334.9 mbsf. Unit III (455-518 mbsf; late early to late Pliocene) is made up of siliceous claystone and claystone. The transition of opal-A to opal-CT coincides with the top of Unit III. Biogenic carbonate is scarce throughout this unit.

\section{SITE 799}

Site 799 is situated in the Kita-Yamato Trough (Fig. 1), at a water depth of $2084 \mathrm{~m}$. Seismic profiles indicate that the sedimentary sequences filling this failed rift basin are as thick as $1200-1400 \mathrm{~m}$ (Shipboard Scientific Party, 1990a,f,g). A 1084.0-m-thick sedimentary section drilled in Holes 799A and 799B has been divided into five lithologic units.

Unit I ( $0-170 \mathrm{mbsf}$; late Pliocene to Quaternary) is similar in lithology and compositions to the Unit I at Site 798, being characterized by distinctive light/dark rhythmic interbeds of bioturbated intervals and thinly laminated layers. Thin turbidite units of foraminiferal sands and a meter-thick slumped interval are conspicuous in this unit. Biogenic carbonate content is mostly between $10 \%$ and $20 \%$. Authigenic calcite and rhodochrosite occur as disseminated crystals or small concretions, $0.5-1.8 \mathrm{~cm}$ in diameter, below 12 mbsf (Matsumoto, this volume). Unit II (170-457 mbsf; late Miocene to late Pliocene) is composed of diatomaceous ooze and diatomaceous clay. Biogenic silica content ranges up to $65 \%$ as measured in smear slides. Terrigenous clay content is less than Unit I and biogenic carbonate content is less than 5\%. The opal-A to opal-CT transition occurs in the lower part of Unit II at around 410-450 mbsf. Millimeter- to centimeterthick beds and lenses and small concretions of calcite, rhodochrosite, dolomite, and lansfordite (hydrous $\mathrm{Mg}$-carbonate) are common throughout this unit (Matsumoto, this volume). Unit III (457-800 mbsf; middle to late Miocene) is made up of siliceous claystone and opal-CT (<528 mbsf) or quartz-porcellanite (585 mbsf). Authigenic calcite, rhodochrosite and magnesite are more abundant in the upper part of Unit III, whereas the carbonate in the lower part is principally dolomite (Matsumoto, this volume). Unit IV (800-1020 mbsf; early to middle Miocene) consists of laminated and bedded siliceous claystone and quartz-porcellanite. Millimeter- to centimeter-thick layers and lenses of dolomite are abundant throughout this unit. Altered rhyolitic tuff and tuff breccia occur between 981 and 1003 mbsf. Unit V (1020-1084 mbsf; early Miocene) is dominantly composed of siliceous claystone and claystone with abundant intercalations of siliciclastic turbidites. 


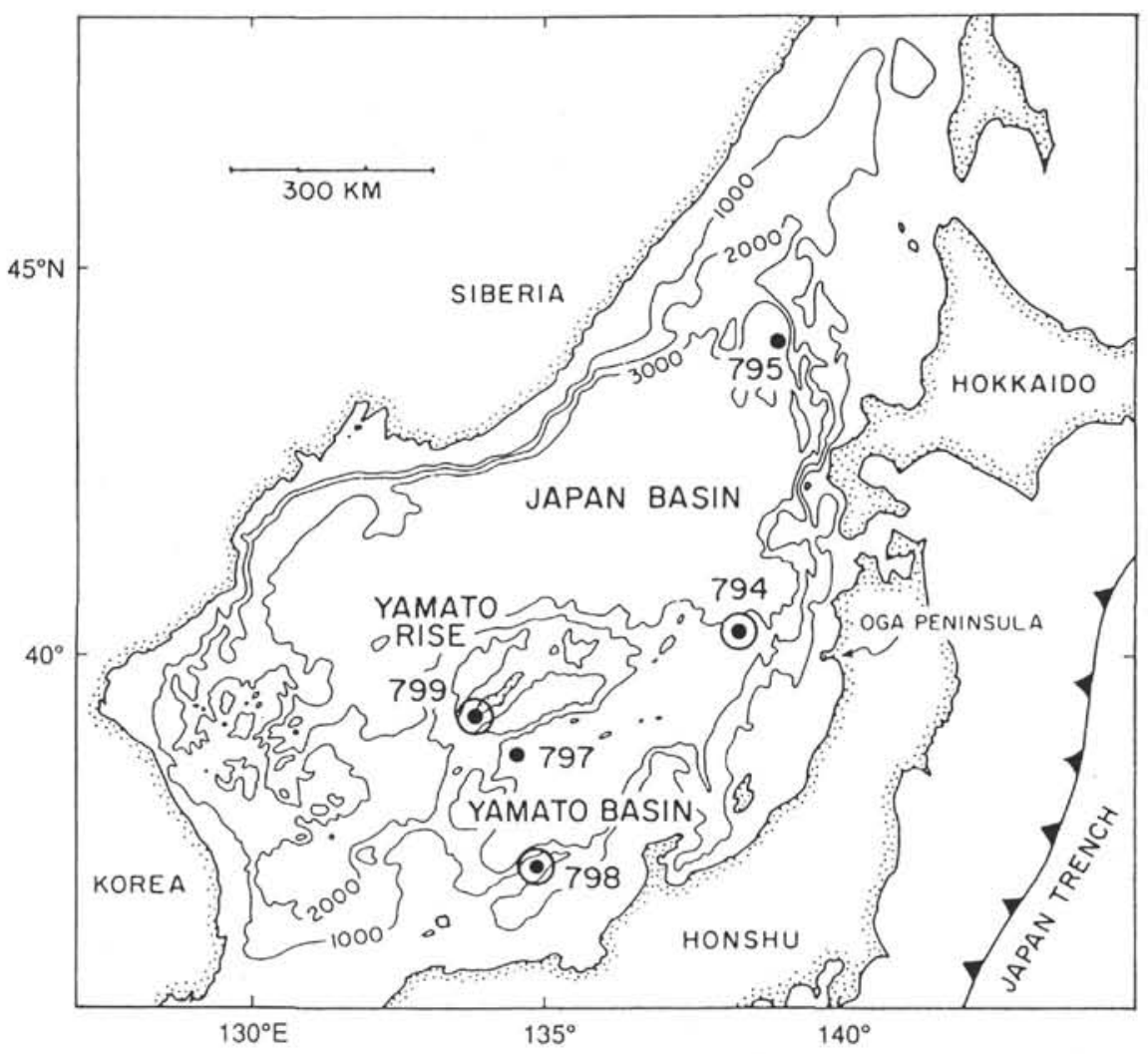

Figure 1. Location map showing bathymetry (in meters) and locations of Sites 794 and 795 in Japan Basin, Site 797 in Yamato Basin, Site 798 on the Oki Ridge, and Site 799 in the Kita-Yamato Trough of Japan Sea.

\section{SAMPLING AND ANALYSIS}

Twenty to $80 \mathrm{~mL}$ of interstitial water were squeezed from core samples $5-10 \mathrm{~cm}$ in length by means of a stainless steel, hydraulic squeezer (Manheim, 1966). Approximately $5 \mathrm{~mL}$ of the water recovered by squeezing were collected in a sealed glass ampule immediately after extraction for isotope analysis. At Site 798, nine interstitial water samples were selected for isotope analyses. Among these, five samples were taken from Unit I and four samples from Unit II. No samples were acquired below the opal-A diagenetic zone. At Site 799, four samples were collected from Unit I and eight samples from Unit II. The deepest sample ( $435.80 \mathrm{mbsf}$ ) from Site 799 is from the opal-A/opal-CT transition zone.

$\mathrm{CO}_{2}$ gas was extracted from $1.5-2.5 \mathrm{~mL}$ aliquots of interstitial waters using the $\mathrm{CO}_{2}-\mathrm{H}_{2} \mathrm{O}$ equilibration method of Epstein and Mayeda (1953). Measurements of the oxygen isotope ratio were made with a Finnigan MAT Delta-E mass spectrometer. Standard deviation for replicate measurements of a single gas sample is less than $0.04 \mathrm{o} \%$. Precision of the method was tested by analyzing two individual $\mathrm{CO}_{2}$ gas extracted from a single interstitial water sample. Two individual aliquots generally agree to better than $0.15 \%$. The results of the analyses are reported in terms of $\delta$ per mil notation relative to SMOW (Table 1).

\section{RESULTS AND DISCUSSION \\ $\delta^{18} \mathrm{O}$-depth Profiles at Sites 798 and 799}

The $\delta^{18} \mathrm{O}$ values at Site 798 range between -0.49 and $-3.38 \%$, with the overall $\delta^{18} \mathrm{O}$-gradient being $-0.70 \%$ oo per $100 \mathrm{~m}$ (Fig. 2). At Site 799 , the $\delta^{18} \mathrm{O}$ values decrease from $-0.71 \mathrm{o} \%$ at $16.6 \mathrm{mbsf}$ to $-4.36 \%$ at $435.8 \mathrm{mbsf}$ with an average depletion gradient of $-0.87 \%$ oper $100 \mathrm{~m}$, similar to that for Site 798 .

The remarkable aspect of $\delta^{18} \mathrm{O}$-depth profiles at Sites 798 and 799 is a large and systematic decrease with depth. This feature is conspicu- ous when compared with somewhat random fluctuation and small gradients in tectonically-deformed accretionary prisms at Sites 582 and 583 in the Nankai Trough and Site 584 of the Japan Trench (Matsuhisa and Matsumoto, 1985). Within accretionary prisms, evolution of water chemistry and isotopic compositions can be significantly affected by migration and mixing of waters along fault planes (e.g., Boulegue and Bariac, 1990). In contrast, a large and systematic decrease at Sites 798 and 799 might be explained as a result of isotopic

Table 1. Oxygen isotopic composition of interstitial waters from Sites 798 and 799.

\begin{tabular}{lrc}
\hline $\begin{array}{c}\text { Hole, core, section, } \\
\text { interval }(\mathrm{cm})\end{array}$ & $\begin{array}{c}\text { Depth } \\
\text { mbsf }\end{array}$ & $\begin{array}{c}\delta^{18} \mathrm{O} \\
\text { \% SMOW }\end{array}$ \\
\hline 798A-1H-1, 145-150 & 1.45 & -0.49 \\
798A-6H-1, 145-150 & 47.65 & -0.92 \\
798B-8H-4, 140-150 & 70.67 & -1.09 \\
798A-12H-4, 145-150 & 109.02 & -1.16 \\
798B-18X-6, 25-35 & 169.47 & -1.29 \\
798B-24X-2, 140-150 & 222.9 & -1.86 \\
798B-30X-2, 140-150 & 279.94 & -2.34 \\
798B-36X-2, 65-75 & 336.75 & -2.94 \\
798B-42X-5, 140-150 & 398.85 & -3.38 \\
799A-3H-4, 135-140 & 16.55 & -0.71 \\
799A-9H-3, 140-145 & 72.70 & -0.96 \\
799A-12H-4, 145-150 & 103.15 & -1.11 \\
799A-18H-4, 145-150 & 161.15 & -1.43 \\
799A-24X-5, 140-145 & 220.50 & -1.88 \\
799A-30X-5, 145-150 & 267.95 & -2.31 \\
799A-33X-5, 145-150 & 295.35 & -2.71 \\
799A-36X-3, 145-150 & 321.35 & -3.40 \\
799A-39X-3, 145-150 & 350.35 & -3.47 \\
799A-42X-4, 145-150 & 380.95 & -3.62 \\
799A-45X-3, 145-150 & 408.35 & -4.11 \\
799A-46X-2, 140-150 & 435.60 & -4.36 \\
\hline
\end{tabular}



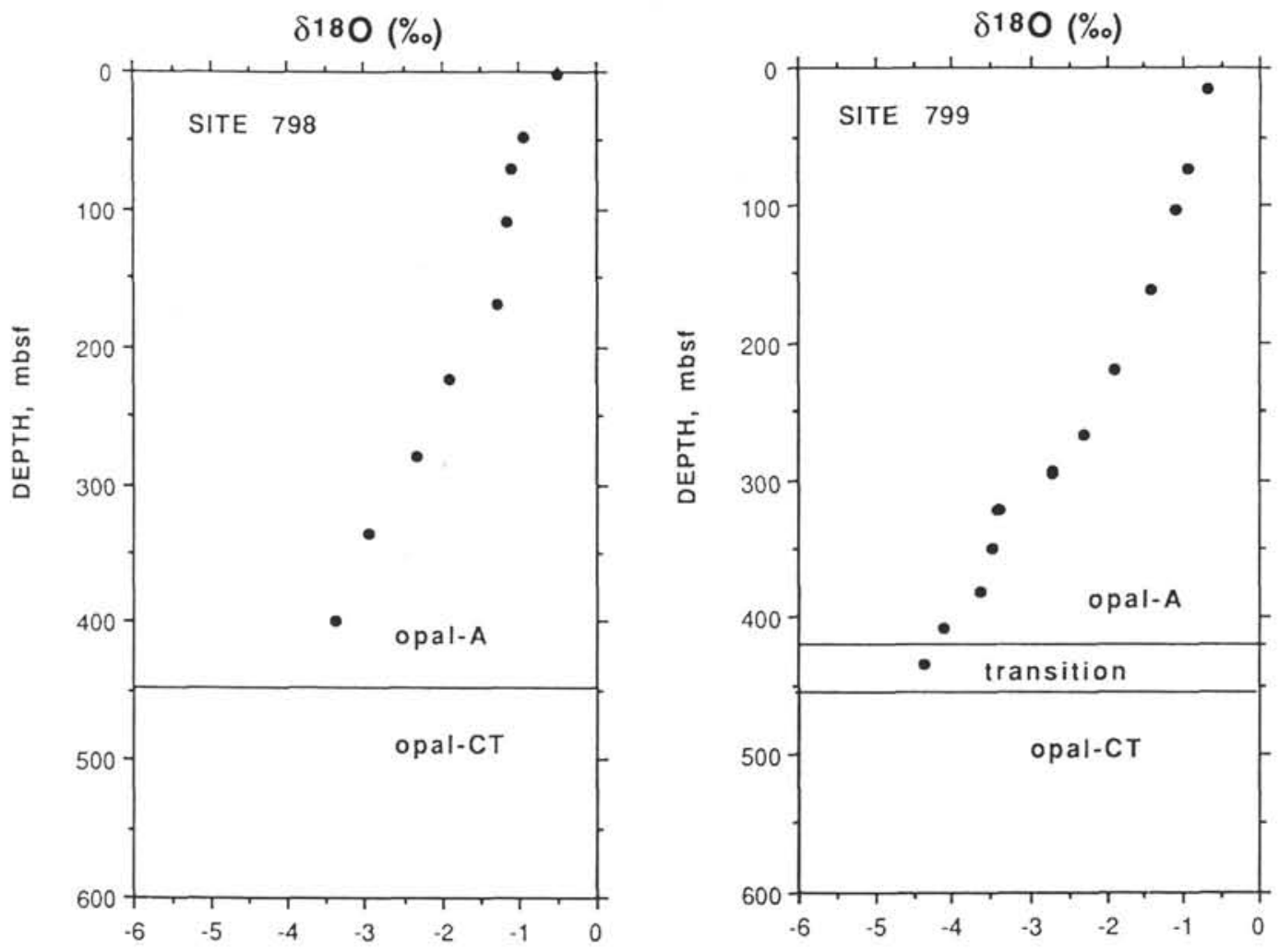

Figure 2. Variations of oxygen isotope composition of the interstitial waters at Sites 798 and 799 of Leg 128 . Zones of silica diagenesis are also given.

exchange between water and sediments and by the alteration of basement rocks during burial diagenesis.

Diagenetic reactions that might be important in controlling $\delta^{18} \mathrm{O}$ of the interstitial waters include (1) low temperature alteration of basalt, (2) alteration of volcanic ash, (3) transformation of biogenic silica (opal-A) through opal-CT to quartz, (4) recrystallization of biogenic carbonates and precipitation of authigenic carbonates, (5) transformation of detrital clay minerals, and (6) formation of gas-hydrates. Several of these may be ruled out or rendered highly unlikely. In particular, formation of gas-hydrates would decrease $\delta^{18} \mathrm{O}$ of ambient interstitial waters (Hesse and Harrison, 1981; Matsumoto, 1989), but this process is not likely to have contributed in changing $\delta^{18} \mathrm{O}$ at Sites 798 and 799, because neither frozen gas-hydrates nor gas-hydrate-related BSR (bottom simulating reflector) have been found in these sites. Possibility (5) can be ruled out, or at least minimized, partly because the sediments at Sites 798 and 799 are dominated with biosiliceous and calcareous components. Also, the transformation of swelling clay minerals to non-swelling clays in Neogene sediments of northern Japan has been found to occur at about $100^{\circ} \mathrm{C}$ (Aoyagi et al., 1987). Clay transformations at such high temperatures would not significantly change $\delta^{18} \mathrm{O}$ of the water (Lawrence, 1973). Therefore, the observed $\delta^{18} \mathrm{O}$-variations at Sites 798 and 799 might be attributed to reactions (1) basalt alteration, (2) ash alteration, (3) silica diagenesis, and (4) carbonate diagenesis. The relative contribution of these reactions in lowering $\delta^{18} \mathrm{O}$ of the interstitial waters are examined using material balance calculations in a closed system model. I will proceed by assessing each of these candidates individually.

\section{Effect of Basalt Alteration}

Sediments at Site 798 and Site 799 directly overlie basaltic rocks as suggested by seismic records and other drilling results. Hole 798A termi- nated only about $190 \mathrm{~m}$ above the acoustic basement, and Hole 799B, 100-300 m above basement (Shipboard Scientific Party, 1990a,f,g).

The $\delta^{18} \mathrm{O}$ values of fresh submarine basalts recovered by DSDP/ ODP drilling cluster around $5.7 \pm 0.3 \%$ (SMOW), whereas those of altered basalts range from 6 to $25 \%$ oo $\delta^{18} \mathrm{O}$ (e.g., Muehlenbachs and Clayton, 1972; Kyser and O'Neil, 1978). The $\delta^{18} \mathrm{O}$-enrichment in the altered basalt has been ascribed to high $\delta^{18} \mathrm{O}$ secondary minerals formed by low temperature alteration. Results from Hole 504B on the East Pacific Rise clearly demonstrate that the uppermost 600 -m-thick pillow basalt section is variably altered and enriched in $\delta^{18} \mathrm{O}$ with an average $\delta^{18} \mathrm{O}$ of $7.0 \%$ oo (Alt et al., 1986). Further, altered terrestrial ophiolites record the substantial isotopic enrichment of the uppermost $1.5-2 \mathrm{~km}$, with $\delta^{18} \mathrm{O}=7-13 \%$ (Stern et al., 1976; Gregory and Taylor, 1981; Cocker et al., 1982).

According to onboard XRF analyses, the entire 200-m-interval of basalt and dolerite at Site 794 has been moderately altered and hydrated, with loss-on-ignition in the range of $0.76 \%-5.01 \%$ (Shipboard Scientific Party, 1990a,f,g). Based on the empirical relationship between $\delta^{18} \mathrm{O}$ and $\mathrm{H}_{2} \mathrm{O}^{+}$of submarine basalt (Muehlenbachs and Clayton, 1972), $\delta^{18} \mathrm{O}$ of Site 794 basalts and dolerites are estimated to be about $10 \%$ (SMOW). The empirical relationship between $\delta^{18} \mathrm{O}$ and age of basalts (Muehlenbachs and Clayton, 1972) also suggests that the early Miocene(?) basalts at Site 799 contain approximately $10-11 \%$ oo (SMOW) of $\delta^{18} \mathrm{O}$.

Assuming that the lowering of $\delta^{18} \mathrm{O}$ of the interstitial waters at Site 799 could be entirely ascribed to the low temperature alteration and ${ }^{18} \mathrm{O}$-enrichment of the underlying basalt, the approximate thickness of altered basalt can be calculated by using a material balance equation:

$$
\mathrm{X}_{\mathrm{B}}\left(\delta_{\mathrm{B} 2}-\delta_{\mathrm{B} 1}\right)+\mathrm{X}_{\mathrm{W}}\left(\delta_{\mathrm{W} 2}-\delta_{\mathrm{W} 1}\right)=0
$$

where, $\mathrm{X}_{\mathrm{B}}, \mathrm{X}_{\mathrm{W}}=$ moles of oxygen of altered basalt and the interstitial water; $\delta_{\mathrm{B} 1}, \delta_{\mathrm{B} 2}=\delta^{18} \mathrm{O}$ of basalt before and after alteration; $\delta_{\mathrm{W} 1} \delta_{\mathrm{W} 2}=$ 
$\delta^{18} \mathrm{O}$ of the interstitial water before and after diagenesis, respectively. $\delta_{\mathrm{B} 1}=5.7 \%$ o (SMOW) and $\delta_{\mathrm{B} 2}=10.0 \%$ o (SMOW) as discussed above, and $\delta_{W_{1}}$ is assumed to be $0 \%$ (SMOW). Contribution of the water contained in basalt is not considered in this calculation, partly because the water contained in basalt is relatively small compared with the interstitial water of the overlying sediments and because $\delta^{18} \mathrm{O}$ of the water contained in basalt is not given. Therefore, the above calculation would give the minimum value for the thickness of altered basalt.

Chemical composition and dry density used for the following calculations have been taken from those of Site 794 basalts (Shipboard Scientific Party, 1990a-g). Site 794 basalt contains 45.99 wt\% oxygen, hence, $1 \mathrm{~g}$ of basalt contains 0.0144 moles of $\mathrm{O}_{2}$. Oxygen molecules contained in basalt of $1 \mathrm{~m}^{3}$ is calculated to be $2.8\left(\mathrm{~g} / \mathrm{cm}^{3}\right) \times 10^{6}\left(\mathrm{~cm}^{3}\right) \times$ 0.0144 (moles $\left.\mathrm{O}_{2} / \mathrm{g}\right)=4.03 \times 10^{4}$ (moles). Therefore,

$$
\begin{gathered}
\mathrm{X}_{\mathrm{B}}\left(\delta_{\mathrm{B} 2}-\delta_{\mathrm{B} 1)}=\left(4.03 \times 10^{4}\right) \times(10.0-5.7)\right. \\
=17.33 \mathrm{~A} \times 10^{4}(\text { moles } \% \text { o })
\end{gathered}
$$

where $\mathrm{A}=$ thickness (in meters) of altered basalt.

Moles of oxygen of the interstitial waters can be obtained from the porosity-depth relationship (Fig. 3; Shipboard Scientific Party, $1990 \mathrm{a}, \mathrm{f}, \mathrm{g}$ ). For the depth ranges of (I) 0-150 mbsf and (II) 150-450 mbsf in Figure 3, sediment porosities are roughly constant at around $70 \%$ and $75 \%$, respectively. For (III) $450-850$ mbsf and (IV) $850+$ mbsf, sediment porosities are given by,

$$
\mathrm{P}=90-0.064 \mathrm{D} \text { and } \mathrm{P}=60-0.026 \mathrm{D}
$$

A

$$
\delta 180(\% \circ)
$$

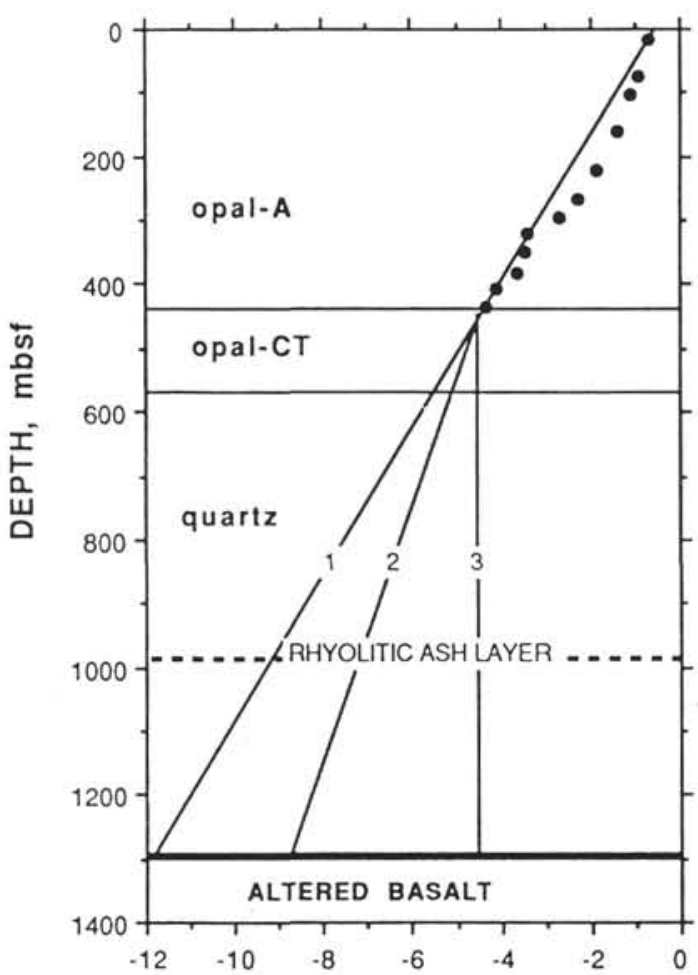

respectively, in which $\mathrm{P}=$ porosity $(\%)$ and $\mathrm{D}=$ depth (in meters). One cubic meter of interstitial waters contains about $2.78 \times 10^{4}$ moles of oxygen. Therefore, the total moles of oxygen contained in the interstitial waters of sediment column with $1 \mathrm{~m}^{2}$ basal area is calculated to be $(\mathrm{P} / 100) \times($ sediment thickness $) \times\left(2.78 \times 10^{4}\right)$.

$\left(\delta_{\mathrm{W} 2}-\delta_{\mathrm{W} 1}\right)$ varies with depth, reflecting $\delta^{18} \mathrm{O}$-depth profiles. For the depth ranges (I) and (II), $\delta^{18} \mathrm{O}=-0.5-0.0087 \mathrm{D}$. Hence, $\delta_{\mathrm{W}_{2}}-\delta_{\mathrm{W} 1}=\delta_{\mathrm{W} 2}=-0.5-0.0087 \mathrm{D}$. For (III) and (IV), where $\delta^{18} \mathrm{O}$ values are not given, three cases are considered as shown by thin solid lines in Figure 3. Case 1 is an extrapolation of the gradients for Zones (I) and (II), in which $\delta_{\mathrm{W} 2}=-0.77-0.0087 \mathrm{D}$. Case 2, $\delta_{\mathrm{w}_{2}}=-2.3-0.005 \mathrm{D}$, was taken from the gradient for opal-CT and quartz zones (approximately $300+$ mbsf) at Sites 794 and 797 (Brumsack, this volume). Case 3 represents the condition that $\delta^{18} \mathrm{O}$ remains constant at $-4.5 \%$ oo.

In general, $\mathrm{X}_{\mathrm{W}}\left(\delta_{\mathrm{W} 2}-\delta_{\mathrm{W} 1}\right)$ is given by an integral equation as,

$$
\mathrm{X}_{\mathrm{W}}\left(\delta_{\mathrm{W} 2}-\delta_{\mathrm{W} 1}\right)=2.78 \times 10^{4} j(\mathrm{P} / 100) \delta_{\mathrm{W} 2} \mathrm{dD}
$$

Equation (3) is integrated for the respective depth range, using $\mathrm{P}$ and $\delta_{\mathrm{W} 2}$ given above. The results are given in Table 2 . Substituting the results in Table 2 in equation (2), the thickness of altered basalt is given as,

Case 1: $\mathrm{A}=547.7 \mathrm{~m}$

Case 2: $\mathrm{A}=480.3 \mathrm{~m}$

Case 3: $\mathrm{A}=379.4 \mathrm{~m}$.

B

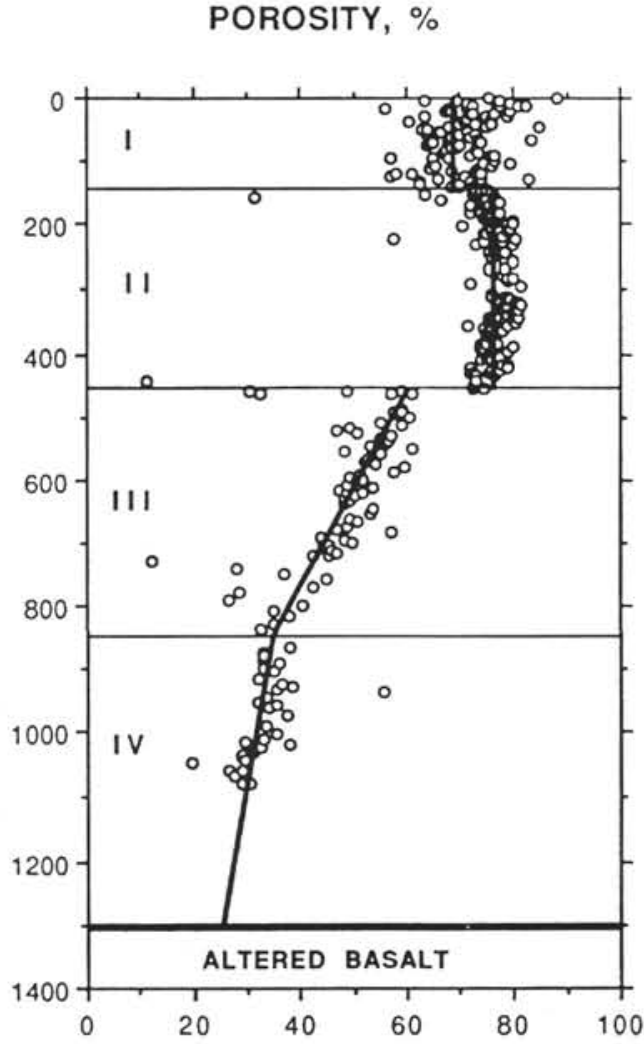

Figure 3. A. Diagram showing $\delta^{18} \mathrm{O}$-depth profiles at Site 799. Diagonal lines represent the gradient below $450 \mathrm{mbsf}$; (1) $-0.87 \%$ oper $100 \mathrm{~m},(2)-0.5 \%$ oper $100 \mathrm{~m}$, and (3) $0 \%$ (constant). Zones of silica diagenesis and depth of thick rhyolitic ash bed are also shown. Total thickness of sediment column has been assumed to be $1300 \mathrm{~m}$ based on seismic records. B. Porosity-depth relations at Site 799. Based on the relation, 1300-m-thick sedimentary section has been divided into four zones, I, II, III, and IV. 
Table 2. Amount of oxygen molecules, $\mathbf{x}_{\mathrm{w}}$, and degree of depletion in ${ }^{18} \mathrm{O}, \mathrm{X}_{\mathrm{W}}\left(\delta_{\mathrm{W}_{2}}-\delta_{\mathrm{W}_{1}}\right)$, of the interstitial waters contained in sediment column with $1 \mathrm{~m}^{2}$ basal area in Holes 799A and 799B.

\begin{tabular}{lcc}
\hline \multicolumn{1}{c}{ Depth zone } & $\begin{array}{c}\mathrm{X}_{\mathrm{W}} \\
\mathrm{mole}_{2}\end{array}$ & $\begin{array}{c}\mathrm{X}_{\mathrm{W}}\left(\delta_{\mathrm{w} 2}-\delta_{\mathrm{W} 1}\right) \\
\text { mole } \%\end{array}$ \\
\hline I (0-150 mbsf) & $2.92 \times 10^{6}$ & $-3.50 \times 10^{6}$ \\
II (150-450 mbsf) & $6.25 \times 10^{6}$ & $-20.00 \times 10^{6}$ \\
III (450-850 mbsf) & $5.33 \times 10^{6}$ & \\
$\quad$ Case 1 & & $-32.39 \times 10^{6}$ \\
$\quad$ Case 2 & & $-29.14 \times 10^{6}$ \\
$\quad$ Case 3 & & $-24.25 \times 10^{6}$ \\
IV (850-1300 mbsf) & $4.00 \times 10^{6}$ & \\
$\quad$ Case 1 & & $-39.03 \times 10^{6}$ \\
$\quad$ Case 2 & & $-30.58 \times 10^{6}$ \\
$\quad$ Case 3 & & $-18.00 \times 10^{6}$ \\
I + II + III + IV & $18.50 \times 10^{6}$ & \\
\hline
\end{tabular}

These values are somewhat similar to the thickness of altered zones observed in Layer II basalt at DSDP/ODP sites and on-land ophiolites, supporting the hypothesis that basalt alteration was responsible for lowering $\delta^{18} \mathrm{O}$ of the interstitial waters at Sites 798 and 799 .

\section{Alteration of Ash Layers}

Sites 798 and 799 sediments are commonly intercalated with ash layers, but most of them are less than $1 \mathrm{~cm}$ in thickness, total thickness being only $1.5 \mathrm{~m}$ at Site 798. However, at Site 799, a thick rhyolitic ash layer, $21.2 \mathrm{~m}$ thick, occurs at 981.3-1002.5 mbsf in Hole 799B. Most of the volcanic glasses in Holes 798A, 798B, and 799A are fresh or very slightly altered, whereas glasses in Hole 799B $(490+$ mbsf $)$ have been totally altered to quartz, smectite, and subordinate iron oxides and rare zeolite (Shipboard Scientific Party, 1990a,f,g). Assuming that volcanic glasses of ash layers in Hole 799B total approximately $23 \mathrm{~m}$ in thickness and have been altered to an aggregate of $50 \%$ quartz and $50 \%$ smectite during burial diagenesis, the effect of ash alteration on $\delta^{18} \mathrm{O}$ may be assessed by material balance calculation:

$$
\begin{gathered}
0.5 \mathrm{X}_{\mathrm{ash}}\left(\delta_{\mathrm{qtz}}-\delta_{\mathrm{gl}}\right)+0.5 \mathrm{X}_{\mathrm{ash}}\left(\delta_{\text {smct }}-\delta_{\mathrm{gl}}\right) \\
+\mathrm{X}_{\mathrm{w}}\left(\delta_{\mathrm{W} 2}-\delta_{\mathrm{W} 1}\right)=0
\end{gathered}
$$

in which, $\mathrm{X}_{\mathrm{ash}}, \mathrm{X}_{\mathrm{w}}=$ oxygen moles in ash layers and interstitial waters responsible for ash alteration, respectively, $\delta_{\mathrm{gl}}, \delta_{\mathrm{qu}}, \delta_{\mathrm{smct}}=\delta^{18} \mathrm{O}$ of fresh glass, authigenic quartz, and authigenic smectite, respectively, $\delta_{\mathrm{w} 1}, \delta_{\mathrm{w} 2}$ $=\delta^{18} \mathrm{O}$ of the interstitial waters before and after ash alteration. $\delta_{\mathrm{W}_{1}}$ is assumed to be $0 \%$ o. Porosity $(34 \%)$ and grain density $\left(2.64 \mathrm{~g} / \mathrm{cm}^{3}\right)$ were taken from those of the thick rhyolitic ash layer (Shipboard Scientific Party, 1990a,f,g). Rhyolitic glass is estimated to contain approximately $47.6 \mathrm{wt} \%$ oxygen, 0.0149 moles of oxygen per $1 \mathrm{~g}$. Hence, oxygen moles in a 23 -m-thick pile of ash layers is calculated to be, $23 \times(1-0.34) \times$ $10^{6} \times 2.64 \times 0.0149=0.60 \times 10^{6} \mathrm{~mole}_{2} . \delta^{18} \mathrm{O}$ values of fresh glass, authigenic quartz, and smectite are assumed to be $10 \%$, $26 \%$ (Lawrence, 1973), and $24 \%$ (Murata and others, 1977), respectively. Substituting these values in equation (4),

$$
\mathrm{X}_{\mathrm{W}} \delta_{\mathrm{W} 2}=-9.0 \times 10^{6}
$$

Supposing that the ash alterations in Hole 799B affected $\delta^{18} \mathrm{O}$ of the interstitial waters in the depth ranges of Zone (III) and (IV), $450-1300$ mbsf, $X_{w}$ is $9.3 \times 10^{6}$ mole $_{2}$ (Table 2), then $\delta_{w_{2}}$ $=-0.98 \%$. This implies that ash alteration in Hole 799B might have lowered $\delta^{18} \mathrm{O}$ of the ambient waters over the depth range of $450-1300 \mathrm{~m}$ by approximately $1 \% 00$. These modeled changes alone are insufficient to account for the observed trend of pore water $\delta^{18} \mathrm{O}$ values.

\section{Silica Diagenesis}

Miocene to Pliocene sediments at Sites 798 and 799 are highly siliceous, ranging in $\mathrm{SiO}_{2}$ content mostly between 62 and $80 \mathrm{wt} \%$ (Minai and others, this volume). As the ratio $\mathrm{Al}_{2} \mathrm{O}_{3} / \mathrm{SiO}_{2}$ for terrigenous suites has been given to be 0.321 (Shipboard Scientific Party, 1990a,f,g), biogenic silica content is calculated by total $\mathrm{SiO}_{2}-\mathrm{Al}_{2} \mathrm{O}_{3} / 0.321$. Based on 32 analyses of diatomaceous clay samples by Minai et al. (this volume), biogenic $\mathrm{SiO}_{2}$ for opal-CT zone is about $22 \mathrm{wt} \%$ and for quartz zone, $39 \mathrm{wt} \%$.

Among 21 water samples examined in this report, only the deepest sample of Site 799 was taken from opal-CT zone (Fig. 3). Probably for this reason, the effect of silica diagenesis has not been clearly recognized at Sites 798 and 799. However at Sites 794, 795, and 797, interstitial waters demonstrate remarkable isotopic enrichment at around opal-A/opal-CT transition (Brumsack, this volume), suggesting that silica diagenesis played an important role in changing $\delta^{18} \mathrm{O}$ of the interstitial waters.

Opal-A contains waters as a trapped form in micropores of the structure and as a hydroxyl form chemically bound to the silicon atoms. The former is in isotopic equilibrium with the ambient waters, but the latter, only about $3 \%$ of oxygen in silica, has isotopic composition of approximately $-40 \%$ compared to the silica (Labeyrie, 1974). Hence, the material balance calculation for silica diagenesis is given by the equation,

$$
\begin{gathered}
\mathrm{X}_{\mathrm{CT}}\left(\delta_{\mathrm{CT}}-\delta_{\mathrm{OP}}\right)+\mathrm{X}_{\mathrm{QT}}\left(\delta_{\mathrm{QT}}-\delta_{\mathrm{OP}}\right)+0.03\left(\mathrm{X}_{\mathrm{CT}}+\mathrm{X}_{\mathrm{QT}}\right) \delta_{\mathrm{H}} \\
+\mathrm{X}_{\mathrm{W}} \delta_{\mathrm{W} 2}-\left(\mathrm{X}_{\mathrm{w}}-0.03\left(\mathrm{X}_{\mathrm{CT}}+\mathrm{X}_{\mathrm{QT}}\right)\right) \delta_{\mathrm{W} 1}=0
\end{gathered}
$$

where $\mathrm{X}_{\mathrm{CT}}, \mathrm{X}_{\mathrm{QT}}, \mathrm{X}_{\mathrm{W}}=$ moles of oxygen in opal-CT, authigenic quartz, and in the interstitial waters, $\delta_{\mathrm{OP}}, \delta_{\mathrm{CT}}, \delta_{\mathrm{QT}}=\delta^{18} \mathrm{O}$ of opal-A, opal-CT, authigenic quartz, $\delta_{\mathrm{H}}=\delta^{18} \mathrm{O}$ of the hydroxyl water originally bound to opal-A, $\delta_{\mathrm{W}_{1}}=0 \% \mathrm{oo}$, and $\delta_{\mathrm{W}_{2}}=\delta^{18} \mathrm{O}$ of the interstitial waters after silica diagenesis. Given the thickness, porosity, and density for the opal-CT zone at Site 799 of $135 \mathrm{~m}$ (450-585 mbsf), 56.5\%, and $2.30 \mathrm{~g} / \mathrm{cm}^{3}$, and for quartz zone, $715 \mathrm{~m}(585-1300 \mathrm{mbs}), 35.3 \%$, and $2.65 \mathrm{~g} / \mathrm{cm}^{3}$ and given the oxygen content of $0.0167 \mathrm{~mole}_{2}$ per $1 \mathrm{~g}$ $\mathrm{SiO}_{2}$, then, the total oxygen content in opal-CT and authigenic quartz in the respective zone are calculated to be $\mathrm{X}_{\mathrm{CT}}=135 \times 0.435 \times 10^{6} \times$ $2.30 \times 0.22 \times 0.0167=0.50 \times 10^{6}\left(\right.$ mole $\left.\mathrm{O}_{2}\right)$ and $\mathrm{X}_{\mathrm{OT}}=715 \times 0.647$ $\times 10^{6} \times 2.65 \times 0.39 \times 0.0167=7.98 \times 10^{6}\left(\right.$ moles $\left.\mathrm{O}_{2}\right)$.

According to the oxygen isotopic study on biosiliceous shale recovered during ODP Leg 127 (Pisciotto et al., this volume), $\delta^{18} \mathrm{O}$ of opal-CT is $25.0 \%$, and quartz, $23.2 \%$ o. $\delta^{18} \mathrm{O}$ value of opal-A is assumed to be $37.4 \%$ (Murata and others, 1977). Hence, $\delta_{\mathrm{CT}}-\delta_{\mathrm{OP}}$ $=25.0-37.4=-12.4 \mathrm{o} \%, \delta_{\mathrm{QT}}-\delta_{\mathrm{OP}}=23.2-37.4=-14.2 \mathrm{o} \%$, and $\delta_{\mathrm{H}}=37.4-40.0=-2.6 \%$ o Supposing that the interstitial waters contained in opal-CT and quartz zone (zones III and IV in Fig. 3) reflect the effect of silica diagenesis, $\mathrm{X}_{\mathrm{w}}$ in equation (5) should be $9.3 \times 10^{6}$ (Table 2). Substituting these values in equation (5),

$$
\delta_{\mathrm{W}_{2}}=141.6 / 9.3=15.2 \% \mathrm{oo}
$$

Silica diagenesis at Site 799 is thus likely to have increased $\delta^{18} \mathrm{O}$ of the ambient waters by approximately $15 \%$. Likewise, the effect of silica diagenesis at Site 798 is roughly calculated to be $7.0 \%$. No isotopic enrichment of the overlying sediments in zones I and II suggests that silica diagenesis did not significantly affect the isotopic trend for the depth range of 0 and 438 mbsf observed in this report.

\section{Carbonate Diagenesis}

Authigenic calcite, dolomite, rhodochrosite, magnesite, and hydro-magnesite occur either as disseminated grains, concretions, and beds with variable size and thickness in Sites 798 and 799 sediments 
(Matsumoto, this volume). In particular Site 799 sediments are commonly intercalated with carbonate concretions and beds. The thickness mostly ranges from 1 to $10 \mathrm{~cm}$, but $>100-\mathrm{cm}$ thick beds have been recognized by borehole logging. The burial depth of precipitation of authigenic carbonates have been estimated to be $0-550 \mathrm{mbsf}$ (Matsumoto, this volume). Some carbonates are considered to have been originated from biogenic carbonates. Recrystallization of biogenic carbonates is not likely to have greatly affected $\delta^{18} \mathrm{O}$ of the interstitial water, because $\delta^{18} \mathrm{O}$ values of recrystallized carbonates are generally quite similar to that of the precursor (Lawrence, 1973; Lawrence et al., 1975). However, carbonate diagenesis at Sites 798 and 799 can dramatically affect pore water isotopic composition, since oxygen isotopes are fractionated during precipitation of authigenic carbonates forming during organic matter decomposition and bacterial fermentation (Matsumoto, this volume). Precipitation of carbonates should lower $\delta^{18} \mathrm{O}$ of interstitial waters because oxygen isotopic fractionations between carbonates and water $\left(10^{3} \ln \alpha_{\text {carb-water }}\right)$ are approximately +35 to $+15 \%$ o at $10^{\circ}-50^{\circ} \mathrm{C}$ (Friedman and $\mathrm{O}^{\prime} \mathrm{Neil}$, 1977). Hence, formation of carbonate concretions and beds might be responsible for the observed $\delta^{18} \mathrm{O}$ variations. Material balance calculation of carbonate precipitation is,

$$
\mathrm{X}_{\mathrm{carb}} \delta_{\mathrm{carb}}+\left(\mathrm{X}_{\mathrm{w}}-\mathrm{X}_{\mathrm{carb}}\right)\left(\delta_{\mathrm{w} 2}-\delta_{\mathrm{w} 1}\right)=0
$$

in which $\mathrm{X}_{\text {carb, }} \mathrm{X}_{\mathrm{w}}=$ moles of oxygen of authigenic carbonates and of the interstitial waters, respectively, before carbonate precipitation, $\delta_{\text {carb }}=$ average $\delta^{18} \mathrm{O}$ of authigenic carbonates, and $\delta_{\mathrm{w} 2}, \delta_{\mathrm{w} 1}=\delta^{18} \mathrm{O}$ of the interstitial waters before and after carbonate precipitation. $\delta_{w 1}=0 \%$.

Authigenic carbonates are estimated to be about $10 \mathrm{vol} \%$ of the host sediments, based on the core descriptions and logging results. This indicates that the equivalent thickness of solid carbonates at Site 799 attains $130 \mathrm{~m}$. Assuming that $50 \%$ of the authigenic carbonates is of "inorganic origin," density of carbonates is $3.2 \mathrm{~g} / \mathrm{cm}^{3}$, and oxygen content in $1 \mathrm{~g}$ of carbonates is 0.0145 moles $\mathrm{O}_{2}$, total moles of oxygen contained in "inorganic" carbonates $\left(=\mathrm{X}_{\text {carb }}\right)$ are $130 \times 10^{6} \times 0.5 \times$ $3.2 \times 0.0145=2.32 \times 10^{5}$ moles $\mathrm{O}_{2}$. The $\delta^{18} \mathrm{O}$ value of authigenic carbonates at Sites 798 and 799 ranges mostly between 20 and 35 $\%$ SMOW (Matsumoto, this volume), averaging $28 \%$. Substituting these values in equation (6),

$$
\begin{gathered}
\delta_{w 2}-\delta_{w 1}=2.32 \times 10^{5} \times(-28) /(185-2.32) \times 10^{5}, \text { then } \\
\delta_{w 2}=-0.36 \% \text { o }
\end{gathered}
$$

This low value of $-0.36 \%$ indicates that carbonate precipitation is not likely to have greatly lowered $\delta^{18} \mathrm{O}$ of the interstitial waters. Even if the "inorganic" carbonates were twice as thick as assumed in the calculations, the effect on $\delta^{18} \mathrm{O}$ is still smaller than $1 \%$. This seems to be consistent with the observations that $\delta^{18} \mathrm{O}$-depth profile at Site 798, in which authigenic carbonates are scarce, is similar to that of Site 799 .

\section{SUMMARY AND CONCLUSIONS}

The isotopic depletion of the interstitial waters from depths of 16.5-436 mbsf at Site 799 describe a trend of isotopic depletion equalling $-0.8 \%$ o per $100 \mathrm{~m}$. A similar trend is recorded for Site 798 over the range of 1.5-337 mbsf. Model results yielded predicted isotopic changes associated with different diagenetic processes. Volcanic ash alteration and carbonate diagenesis-respectively capable of decreasing ambient $\delta^{18} \mathrm{O}$ by $1 \% \%$ and $0.4 \%$-are insufficient to account for the observed trend. The amount of depletion in ${ }^{18} \mathrm{O}$ of the interstitial waters at Site 799 correspond roughly to predicted changes associated with low temperature alteration of basement basalt to the approximate depth of $380-550 \mathrm{~m}$.
Taking the negative effects of ash alterations and carbonate diagenesis into account and considering the fact that submarine basalt and on-land ophiolites have usually been altered to the depth up to $1 \mathrm{~km}$, the magnitude of isotopic depletion observed at Sites 798 and 799 is smaller than expected. This discrepancy can be interpreted as a result of (1) positive shifts caused by silica diagenesis, and (2) flux of isotopically light waters into the ocean from sediment piles due to compaction. $\delta^{18} \mathrm{O}$ of interstitial waters in opal-CT and quartz zones has been increased by approximately $7 \%$ (Site 798) and $15 \%$ (Site 799) by a singular effect of silica diagenesis. This effect would largely compensate the negative effects caused by basalt alterations, ash alterations, and carbonate diagenesis.

In conclusion, $\delta^{18} \mathrm{O}$-depth profiles at Sites 798 and 799 are largely attributable to the negative shift by basalt alteration and subordinately positive shift by silica diagenesis. To elucidate the effect of these offsetting processes, and their effect upon $\delta^{18} \mathrm{O}$ of overlying seawater, the $\delta^{18} \mathrm{O}$-depth profiles for the entire sediment column should be determined.

\section{ACKNOWLEDGMENTS}

I am grateful to Drs. James R. Hein, Steven R. Chambers, Yukihiro Matsuhisa, Ken Pisciotto, and Mr. Kurt Grimm for their constructive comments and discussions. Dr. Brumsack provided me with unpublished data of pore water $\delta^{18} \mathrm{O}$ values at Sites $794,795,796$, and 797 of Leg 127. This research has been financially supported by Grant-in-Aid from the Ministry of Education (Grant Nos. 01540625 and 03543054).

\section{REFERENCES}

Alt, J. C., Muehlenbachs, K., and Honnorez, J., 1986. An oxygen isotopic profile through the upper kilometer of the oceanic crust, DSDP Hole 504B. Earth. Plant. Sci. Lett., 80:217-229.

Aoyagi, K., Chilingaian, G. V., and Yen, T. F., 1987. Clay mineral diagenesis in argillaceous sediments and rocks. Energy Sources, 9:99-109.

Bath, A., and Shackleton, N., 1984. Oxygen and hydrogen isotope studies in squeezed pore waters, Deep Sea Drilling Project Leg 74, Hole 525B: evidence for mid-Miocene ocean isotopic change. In Moore, T. C., Jr., Rabinowitz, P. D., et al., Init. Repts. DSDP, 74: Washington (U.S. Govt. Printing Office), 697-699.

Boulegue, J., and Bariac, T., 1990. Oxygen and hydrogen isotope ratios of Interstitial waters from an intraplate deformation area: Bengal Fan, Leg 116. In Cochran, J. R., Stow, D.A.V., et al., Proc. ODP, Sci. Results, 116: College Station, TX (Ocean Drilling Program), 127-133.

Cocker, J. D., Griffin, B. J., and Muehlenbachs, K., 1982. Oxygen and carbon isotope evidence for sea-water-hydrothermal alteration of the Macquarie Island ophiolite. Earth Planet. Sci. Lett., 61:112-122.

Epstein, S., and Mayeda, T., 1953. Variation of ${ }^{18} \mathrm{O}$ content of waters from natural sources. Geochim. Cosmochim. Acta, 4:213-224.

Freidman, I., and O'Neil, J. R., 1977. Compilation of stable isotope fractionation factors of geochemical interest. Geol. Surv. Prof. Pap. U.S., $440-\mathrm{K}: 12$.

Gregory, R. T., and Taylor, H. P., Jr., 1981. An oxygen isotope profile in a section of Cretaceous oceanic crust, Samail ophiolite, Oman: evidence for $\delta^{18} \mathrm{O}$ buffering of the oceans by deep $(>5 \mathrm{~km})$ seawater-hydrothermal circulation at mid-ocean ridges. J. Geophys. Res., 86:2737-2755.

Hesse, R., and Harrison, W. E., 1981. Gas hydrates (Clathrates) causing pore-water freshening and oxygen isotope fractionation in deep-sea sedimentary sections of terrigenous continental margins. Earth Planet. Sci. Lett., 55:453-462.

Jenden, P. D., and Gieskes, J. M., 1983. Chemical and isotopic composition of interstitial water from deep-sea drilling project Sites 533 and 534. In Sheridan, R. E., Gradstein, F. M., et al., Init. Repts. DSDP, 76: Washington (U.S. Govt. Printing Office), 453-462.

Kyser, T. K., O'Neil, J. R., and Carmichael, I.S.E., 1982. Genetic relations among basic lavas and ultramafic nodules: evidence from oxygen isotope compositions. Contrib. Mineral. Petrol., 81:88-102.

Lawrence, J. R., 1973. Interstitial water studies, Leg 15. In Heezen, B. C., MacGregor, I. D., et al., Init. Repts. DSDP, 20: Washington (U.S. Govt. Printing Office), 891-899. 
Lawrence, J. R., Gieskes, J. M., and Broecher, W. S., 1975. Oxygen isotope and cation composition of DSDP pore waters and the alteration of layer II basalts. Earth Planet. Sci. Lett., 27:1-10.

Manheim, F. T., 1966. A hydraulic squeezer obtaining interstitial water from consolidated and unconsolidated sediments. Geol. Surv. Prof. Pap. U.S., 550-C:256.

Matsuhisa, Y., and Matsumoto, R., 1985. Oxygen isotope ratios of interstitial waters from the Nankai trough and the Japan trench, Leg 87. In Kagami, H., Karig, D. E., Coulbourn, W. C., et al., Init. Repts. DSDP, 87:853-856.

Matsumoto, R., 1989. Isotopically heavy oxygen-containing siderite derived from the decomposition of methane hydrate. Geology, 17:707-710.

Muehlenbachs, K., 1986. Alteration of the ocean crust and ${ }^{18} \mathrm{O}$ history of seawater. In Valley, J. W., Taylor, H. P., Jr., and O'Neil, J. R. (Eds.), Stable Isotopes in High Temperature Geological Processes. Rev. Mineral., 16:425-444.

Muehlenbachs, K., and Clayton, R. N., 1972. Oxygen isotope studies of fresh and weathered submarine basalts. Can. J. Earth Sci., 9:471-478.

Murata, K. J., Freidman, I., and Gleason, J. D., 1977. Oxygen isotope relations between diagenetic silica minerals in Monterey Shale, Temblor Range, California. Am. J. Sci., 277:259-272.

Shipboard Scientific Party, 1990a. Site 794. In Ingle, J. C., Jr., Suyehiro, K. von Breymann, M. T., et al., Proc. ODP, Init. Repts., 128: College Station, TX (Ocean Drilling Program), 67-120.

, 1990b. Site 794. In Tamaki, K., Pisciotto, K., Allan, J., et al., Proc. ODP, Init. Repts., 127: College Station, TX (Ocean Drilling Program), 71-167.

, 1990c. Site 795. In Tamaki, K., Pisciotto, K., Allan, J., et al., Proc. ODP, Init. Repts., 127: College Station, TX (Ocean Drilling Program), 169-245. 1990d. Site 796. In Tamaki, K., Pisciotto, K., Allan, J., et al., Proc. ODP, Init. Repts., 127: College Station, TX (Ocean Drilling Program), $246-322$.

, 1990e. Site 797. In Tamaki, K., Pisciotto, K., Allan, J., et al., Proc. ODP, Init. Repts., 127: College Station, TX (Ocean Drilling Program), $323-421$.

1990f. Site 798. In Ingle, J. C., Jr., Suyehiro, K., von Breymann, M. T., et al., Proc. ODP, Init. Repts., 128: College Station, TX (Ocean Drilling Program), 121-236.

, 1990g. Site 799. In Ingle, J. C., Jr., Suyehiro, K., von Breymann, M. T. et al., Proc. ODP, Init. Repts., 128: College Station, TX (Ocean Drilling Program), 237-402.

Stern, C., de Wit, M. J., and Lawrence, J. R., 1976. Igneous and metamorphic processes associated with the formation of Chilean ophiolites and their implication for ocean floor metamorphism, seismic layering, and magnetism. J. Geophys. Res., 81:4370-4380.

Vrolijk, P., Chambers, S. R., Gieskes, J. M., and O’Neil, J. R., 1990. Stable isotope ratios of interstitial fluids from the northern Barbados accretionary prism, ODP Leg 110. In Moore, J. C., Mascle, A., et al., Proc. ODP, Sci. Results, 110: College Station, TX (Ocean Drilling Program), 189-205.

Date of initial receipt: 18 March 1991

Date of acceptance: 19 February 1992

Ms 127/128B-178 